Chairmanship of Professor L. S. Penrose, with Dr. B. W. Richards as Editor.

Articles on all aspects of mental deficiency will be included, but there will be a medical bias and a high proportion of available space will be allotted to papers reporting the results of original research.

The journal will appear twice a year in the first instance and will become quarterly should this be justified by the quantity and quality of subject matter submitted. The journal will cost $7 \mathrm{~s}$. $6 \mathrm{~d}$. per number, or one dollar fifty cents.

Subscriptions should be forwarded to: The Publishing Manager, Mr. A. Highfield, 10 Shendon Way, Sevenoaks, Kent, and enquiries and contributions to: Dr. B. W. Richards, St. Lawrence's Hospital, Caterham, Surrey.

\section{Foundations' Fund for Research in Psychiatry}

The Foundations' Fund for Research in Psychiatry wishes to announce that October 15, 1957, is the next deadline for the submission of applications for research fellowships and research teaching grants in psychiatry, psychology, sociology, neurophysiology, and other sciences relevant to mental health. Interested persons and departments are invited to write for details to:

Foundations' Fund for Research in Psychiatry, 251 Edwards Street, New Haven 11, Connecticut.

Correction.--The following corrections should be made in the paper entitled "The Recurrence of Intracranial Meningiomas after Surgical Treatment" by Donald Simpson, published in the February issue $(20,22)$.

Page 25, column 1, line 49: for Fig. 1 read Table II.

Page 31, column 1, line 23: omit the words " Case 6 in Table $\mathrm{V}$ of Linell's series".

Page 32, the legend to Fig. 12 should read: Pulmonary metastasis from the same tumour.

(a) Haematoxylin-Van Gieson $\times 70$. (b) Haematoxylin and eosin $\times 160$.

Page 33, the legend to Fig. 13 should read : A fibroblastic meningioma appearing to be of very rapid growth.

(a) Haematoxylin-Van Gieson $\times$ 470. (b) Reticulin $\times 470$.

The legend to Fig. 14 should read: An angioblastic meningioma of the Sylvan fissure, clinically benign.

(a) Haematoxylin-Van Gieson $\times 210$. (b) Reticulin $\times 210$.

PAge 34, the legend to Fig. 15 should read: An angioblastic meningioma of the cerebral convexity, also clinically benign.

(a) Haematoxylin and eosin $\times 210$. (b) Reticulin $\times 210$.

\section{BOOKS RECEIVED}

(Review in a later issue is not precluded by notice here of books recently received.)

An Atlas of Muscle Pathology in Neuromuscular Diseases. By J. Godwin Greenfield, G. Milton Shy, Ellsworth C. Alvord, and Leonard Berg. (Pp. ix +104; illustrated. 45s.) Edinburgh and London: E. \& S. Livingstone. 1957.

Les Tumeurs Frontales. Edited by Jacques Boudouresques and Joel Bonnal. (Pp. 243; illustrated.) Paris: Masson.

Modern Trends in Neurology (Second Series). Edited by Denis Williams. (Pp. $\mathrm{xi}+350+$ Index; 80 figures. 72s. 6d.) London: Butterworth. 1957.

The Early Diagnosis and Treatment of Acoustic Nerve Tumors. By J. Lawrence Pool and Arthur A. Pava. (Pp. viii +161; 33 figures. 42s.) Oxford: Blackwell; Springfield (Illinois): Charles C. Thomas. 1957.

Spinal Cord Compress. By I. M. Tarlov. (Pp. xiv +147; 41 figures. 57s. 6d.) Oxford: Blackwell; Springfield (Illinois): Charles C. Thomas. 1957.

Schizophrenia: Somatic Aspects. By various authors, edited by Derek Richter. (Pp. viii+180; illustrated. 40s.) London and New York: Pergamon Press. 1957.

Instinct in Man: In the Light of Recent Work in Comparative Psychology. By Ronald Fletcher. (Pp. 348. 40s.) London: Allen \& Unwin. 1957.

Perceptual Processes and Mental Illness (Maudsley Monographs No. 2). By H. J. Eysenck, G. W. Granger, and J. C. Brengelmann. (Pp. 144. 25s.) London: Chapman \& Hall. 1957.

The Physiology of Nerve Cells. By John Carew Eccles. (Pp. ix + 270; 80 figures. 30s.) London: Oxford University Press. 1957.

Précis de Biologie Humaine. By Paul Chauchard. (Pp. xii+403; 59 figures.) Paris: Presses Universitaires de France. 1957.

An Introduction to Electromyography. By Fritz Buchthal. (Pp. 43; 8 figures.) Copenhagen: Gyldendals Presseafdeling. 1957.

Kraepelin und Freud. By Kurt Kolle. (Pp. 88. DM7.60.) Stuttgart: Georg Thieme. 1957.)

An Introduction to Psychopathology. By D. Russell Davis. (Pp. vi+388. 30s.) London: Oxford University Press. 1957.

Brains and Consciousness. By Hartwig Kuhlenbeck. (Pp. 348; 22 figures. Sw.frs. 34.60.) Basel: S. Karger. 1957.

Pain and Pleasure. By Thomas S. Szasz. (Pp. xvi +301. \$5.50.) New York: Basic Books. 1957.

Hospital Treatment of Alcoholism. By Robert S. Wallerstein and Associates, with an Introduction by Karl A. Menninger. (Pp. $x+212$. \$5.00.) New York: Basic Books. 1957. 